\title{
The Prosperity Ethic
}

\section{Neoliberal Christianity and the Rise of the New Prosperity Gospel in the Philippines}

\author{
Erron Medina \\ Development Studies Program, Ateneo de Manila University, Quezon City, \\ Philippines \\ emedina@ateneo.edu \\ Jayeel Cornelio \\ Development Studies Program, Ateneo de Manila University, Quezon City, \\ Philippines \\ Corresponding author:jcornelio@ateneo.edu
}

\begin{abstract}
A new prosperity gospel is emerging in the Philippines. We call it the prosperity ethic. Its dimensions set it apart from the previous incarnation of the prosperity gospel, which emphasized tithing and confessing. Specifically, the prosperity ethic values upward mobility and uses biblical principles for the acquisition of practical skills to become rich. We make our case by drawing on the writings of Bo Sanchez and Chinkee Tan, two of the most influential prosperity-oriented preachers in the country. The prosperity ethic has three dimensions: the morality of wealth (believing right), the prescribed mindset (thinking right), and the practical skills to accumulate wealth (doing it right). In the latter part we explain the rise of the prosperity ethic by relating it to major shifts in the economy since the 199os. For sanctifying individual hard work and desire, the new prosperity gospel is emblematic of neoliberal Christianity in the Philippines today.
\end{abstract}

\section{Keywords}

prosperity gospel - prosperity ethic - neoliberalism - Christianity - Philippines 
The prosperity gospel has been a long-standing marker of contemporary Christianity in the Philippines. It preaches that material wealth and physical health are God's will for believers. ${ }^{1}$ Its seeds were sown in the 1980 os in charismatic circles around the country. It was a time when many new congregations and prayer groups-Catholic and otherwise-attracted low-income followers. ${ }^{2}$ Social and civic engagements characterized the activities of these churches, but over time, they became increasingly prosperity-oriented. The prosperity gospel provided the religious language for the material aspirations of many Filipinos. It became most influential with the success of El Shaddai, a Catholic renewal movement led by Brother Mike Velarde. ${ }^{3}$

Today the prosperity gospel is discernible in messages preached in churches all over the country. This observation complements a ten-country survey run by Pew Research, which revealed that 85 percent of Charismatics agreed that "God will grant material prosperity to all believers who have enough faith." ${ }^{4}$ For Filipino theologian Joel Tejedo, this is the case, too, for pentecostal megachurches, which are among the most influential religious institutions in the Philippines. He observes that "due to their links to Western Christianity, [pentecostal megachurches] continue to be triumphalist and have developed a theology of prosperity often expressed in their preaching. ${ }^{5}$

This article proposes that a shift has taken place. We call this the rise of the prosperity ethic. Its dimensions set it apart from the previous incarnation of the prosperity gospel, which emphasized tithing and confessing. Specifically, the prosperity ethic values upward mobility and uses biblical principles to justify the acquisition of practical skills to become rich. We make our case by drawing on the writings of Bo Sanchez and Chinkee Tan, two of the most influential

1 Amos Yong, "A Typology of Prosperity Theology: A Religious Economy of Global Renewal or Renewal Economics?," in Pentecostalism and Prosperity: The Socioeconomics of the Global Charismatic Movement, ed. Katherine Attanasi and Amos Yong (New York: Palgrave Macmillan, 2012), 15-34.

2 Jayeel Cornelio, "The Philippines," in Edinburgh Companions to Global Christianity: Christianity in East and South-East Asia, ed. Kenneth Ross, Todd Johnson, and Francis Alvarez (Edinburgh: Edinburgh University Press, 2020); Joel Tejedo, "Pentecostal-Charismatic Megachurches in the Philippines," in Pentecostal Megachurches in Southeast Asia:Negotiating Class, Consumption and the Nation, ed. Terence Chong (Singapore: ISEAS, 2018), 156-178.

3 Katharine Wiegele, Investing in Miracles: El Shaddai and the Transformation of Popular Catholicism in the Philippines, Southeast Asia: Politics, Meaning and Memory (Honolulu, Hawaii: University of Hawaii Press, 2005).

4 Pew Research Center, "Spirit and Power: A 1o-Country Survey of Pentecostals," The Pew Forum on Religion \& Public Life (Washington, DC: Pew Research Center, October 2006), 30, http:// www.pewforum.org/2006/10/o5/spirit-and-power/.

5 Tejedo, "Pentecostal-Charismatic Megachurches in the Philippines," 170. 
prosperity-oriented preachers in the country. The prosperity ethic has three dimensions: the morality of wealth (believing right), the prescribed mindset (thinking right), and the practical skills to accumulate wealth (doing it right).

In the latter part we explain the rise of the prosperity ethic by relating it to major shifts in the economy since the 198 os. $^{6}$ We will argue that the prosperity ethic is an aspirational discourse that sacralizes the work of the neoliberal laborer. Put differently, it is the sanctification of individual hard work and desire. The merit of our work is that although these shifts are discernible in the Philippines, they can inform how other scholars as well might assess transformations to the prosperity gospel elsewhere.

\section{The Prosperity Gospel}

The major claim of the prosperity gospel is that material and spiritual provisions are a result of faith-driven obedience to divine commandments. ${ }^{7}$ Specifically, faith "is an activator, a power that unleashes spiritual forces and turns the spoken word into reality." In the American context, faith, wealth, health, and victory are its four main themes. Believers have a "special form of Christian power to reach into God's treasure trove" to elicit physical and financial miracles. ${ }^{9}$ In what follows, we spell out the foundations and key themes of the prosperity gospel based on the literature before presenting the economic turn in recent scholarship. We begin with a discussion of the American prosperity gospel because it lays the historical and analytical foundations for the rise of Brother Mike, forerunner of the prosperity preaching in the Philippines. As will be shown later, the prosperity gospel continues to influence Filipino preachers

6 Cornelio, "The Philippines"; Jayeel Cornelio, "Popular Religion and the Turn to Everyday Authenticity: Reflections on the Contemporary Study of Philippine Catholicism," Philippine Studies: Historical and Ethnographic Viewpoints 62, no. 3 (2014): 471-50o; Jayeel Cornelio and Erron Medina, "Prosperity Ethic: The Rise of the New Prosperity Gospel," in The Routledge International Handbook of Religion in Global Society, ed. Jayeel Cornelio et al. (London and NY: Routledge, 2021).

7 Stephen Hunt, "Dramatising the 'Health and Wealth Gospel': Belief and Practice of a NeoPentecostal 'Faith' Ministry," Journal of Beliefs and Values 21, no. 1 (2000): 73-86, https://doi .org/10.1080/13617670050002345; Thomas Mboya, "Gift Challenges and Transforms Prosperity Gospel," African Ecclesial Review 58, no. 1 \& 2 (2016): 16.

8 Kate Bowler, Blessed:A History of the American Prosperity Gospel (New York: Oxford University Press, 2013), 7 .

9 Daisy Machado, "Capitalism, Immigration, and the Prosperity Gospel," Anglican Theological Review 92, no. 4 (2010): 723-730. 
and authors, who, apart from appropriating the English language in their writing, also refer to American preachers for inspiration.

\subsection{Foundations}

The prosperity gospel traces its roots in Pentecostal Christianity and the New Thought Movement. ${ }^{10}$ While there are many strands of Pentecostal thought, its basic premise emphasizes spiritual experiences: having a personal relationship with God and encountering the work of the Holy Spirit, typically in the form of healing, prophecy, and speaking in tongues. ${ }^{11}$ These gifts are life-changing and empowering to believers. ${ }^{12}$ As a result, Pentecostalism's impact is felt immediately among marginalized communities around the world.

The prosperity gospel finds its origins, too, in the New Thought movement, which espouses financial success and healing. ${ }^{13}$ The movement can be traced back to some influential American preachers, such as Phineas Quimby, Norman Vincent Peale, E.W. Kenyon, Kenneth Hagin, Pat Robertson, and Oral Roberts. ${ }^{14}$ For emphasizing the power of the mind, it is a metaphysical religion that believes that individuals have extraordinary powers to access "multiple cosmic worlds" and "psychic energy" to attain healing. ${ }^{15}$ In addition, it believes in the union of God and the human mind, the superiority of spiritual reality over matter, and the generative power of positive thinking. ${ }^{16}$ The mind, as it were, can make things happen in the material world.

10 Simon Coleman, The Globalisation of Charismatic Christianity: Spreading the Gospel of Prosperity (Cambridge, UK: Cambridge University Press, 200o); Dawn Hutchinson, "New Thought's Prosperity Theology and Its Influence on American Ideas of Success," Nova Religio: The Journal of Alternative and Emergent Religions 18, no. 2 (2014): 28-44; Joel Robbins, "The Globalization of Pentecostal and Charismatic Christianity," Annual Review of Anthropology 33 (2004): 117-143; Isabelle Barker, "Charismatic Economies: Pentecostalism, Economic Restructuring, and Social Reproduction," New Political Science 29, no. 3 (2007): 407-427; Catherine Albanese, A Republic of Mind and Spirit: A Cultural History of American Metaphysical Religion (New Haven and London: Yale University Press, 2007); Attanasi, "Introduction," 3.

11 Pew Research Center, "Spirit and Power: A 10-Country Survey of Pentecostals"; Pew Research Center, "Global Christianity—A Report on the Size and Distribution of the World's Christian Population" (Pew Research Center, 2011), https://www.pewforum.org/2011/12/19/ global-christianity-movements-and-denominations/.

12 David Martin, Pentecostalism: The World Their Parish (Malden, MA and Oxford: Blackwell Publishing, 2001).

13 Bowler, Blessed.

14 Coleman, The Globalisation of Charismatic Christianity.

15 Albanese, A Republic of Mind and Spirit, 13-15.

16 Bowler, Blessed, 12. 
The affinity between New Thought and pentecostal Christianity is evident in that they have both engendered pragmatism, individualism, and desire for upward mobility. ${ }^{17}$ Both afford ordinary individuals unprecedented access to life-changing power. Over time, the theological development of the prosperity gospel would be found in many preachers behind the "Word of Faith" movement. ${ }^{18}$ It proclaims that God, through the death of Christ, has already provided all the needs of humanity, including spiritual, physical, and economic success. ${ }^{19}$ The theological basis is that "sickness and poverty" are "vestiges of Satan's dominion over the earth" that Christ's death and resurrection have effectively ended. ${ }^{20}$ For pentecostal churches-and later on, the charismatic movement-personal salvation, faith, and the experience of material wellbeing are all the privilege of renewed believers. Prosperity and personal breakthroughs are now understood as functions of personal beliefs, miracles, and individual responsibility. ${ }^{21}$ The role, then, of the Christian is to claim this new reality by confessing biblical promises. The irony of it all is that when it began, pentecostal Christianity "shunned lavish living as worldliness that brought enmity from God."22

\section{$1.2 \quad$ Economic Turn}

As it intersects with local contexts, the prosperity gospel takes on a life of its own with respect to people's quality of life. ${ }^{23}$ The economic turn in the literature is an important theme to which our study relates. Two strands matter here. The first is on the effect of beliefs on individual mobility and economic development. ${ }^{24}$ For some scholars, the prosperity gospel promotes an entrepreneurial mindset in unlocking economic breakthroughs. ${ }^{25}$ Psycholo-

17 Bowler, Blessed, 11.

18 Simon Coleman, "The Faith Movement: A Global Religious Culture?," Culture and Religion 3, no. 1 (2002): 8, https://doi.org/10.1080/01438300208567180; Shayne Lee, "Prosperity Theology: T.D. Jakes and the Gospel of the Almighty Dollar." CrossCurrents 57, no. 2 (2007): 227-236. http://www.jstor.org/stable/24461367.

19 Päivi Hasu, "World Bank \& Heavenly Bank in Poverty \& Prosperity: The Case of Tanzanian Faith Gospel," Review of African Political Economy 33, no. 110 (2006): 679.

$20 \quad$ Attanasi, "Introduction," 5.

21 Ebenezer Obadare, “'Raising Righteous Billionaires':The Prosperity Gospel Reconsidered,” HTS Teologiese Studies/ Theological Studies 72, no. 4 (2016): 4.

22 Lee, "Prosperity Theology," 227.

23 Attanasi, "Introduction: The Plurality of Prosperity Theologies and Pentecostalisms."

24 Rachel McCleary and Robert Barro, The Wealth of Religions: The Political Economy of Believing and Belonging (Princeton and Oxford: Princeton University Press, 2019).

25 Naomi Haynes, "Pentecostalism and the Morality of Money: Prosperity, Inequality, and Religious Sociality on the Zambian Copperbelt," Journal of the Royal Anthropological Institute 18 (2012): 125-128. 
gists argue that the power of the prosperity gospel lies in evoking positive emotions that enhance optimism and financial risk-taking. ${ }^{26}$ Looking beyond the individual, scholars have also recognized its role in globalizing capitalism. Many megachurches and their charismatic preachers are connected through a global network that circulates their messages, songs, and publications that celebrate abundance and wealth. ${ }^{27}$

The second strand concerns how the prosperity gospel mirrors the marketization of society ${ }^{28}$ Churches and their entrepreneurial leaders play an active role in commodifying spiritual experience to offer a religious brand that relates to its intended audience..$^{29}$ Joel Osteen, a prosperity-oriented preacher based in Texas, is a leading figure for linking happiness to consumption. Such themes as ever-increasing discretionary consumption and financial prosperity are central to his theology of the good life..$^{30}$ Osteen's first book, Your Best Life Now, explains that people's ability to enjoy God's blessing is hindered by their feelings of unworthiness. ${ }^{31}$ Thus the prosperity gospel "transforms its practitioners from loyal citizens into consumers of religious markets." ${ }^{32}$ The transformation happens as the attainment of material affluence becomes "salvific in itself." 33

In effect, that the prosperity gospel mirrors the marketization of society points to what Tremlett describes as neoliberal Christianity in the Philippines. $^{34}$ To him, prosperity movements in the country provide the religious

26 Nicholas Hobson, Juensung Kim, and Geoff MacDonald, "A Camel through the Eye of a Needle: The Influence of the Prosperity Gospel on Financial Risk-Taking, Optimistic Bias, and Positive Emotion," Psychology of Religion and Spirituality (November 2018), DOI: 10.1037/reloooo235.

27 Michael Wilkinson, "The Prosperity Gospel and the Globalization of American Capitalism," in Religious Activism in the Global Economy: Promoting, Reforming, or Resisting Neoliberal Globalization?, ed. Sabine Dreher and Peter Smith (London: Rowman \& Littlefield, 2016), 57-72.

28 Marcus Moberg and Tuomas Martikainen, "Religious Change in Market and Consumer Society: The Current State of the Field and New Ways Forward," Religion 48, no. 3 (2018): 418-435.

29 Jeaney Yip and Susan Ainsworth, "You Need 'Help for the Journey': Freedom and Regulation in a 'Market-Friendly' Megachurch," Marketing Theory 20, no. 1 (2020): 103-121.

$30 \quad$ Peter Mundey, "The Prosperity Gospel and the Spirit of Consumerism according to Joel Osteen," Pneuma 39, no. 3 (2017): 337.

31 Russell Johnson, "The Gospel and the Prosperity Gospel: Joel Osteen's Your Best Life Now Reconsidered," Theology 121, no. 1 (2018): 3 o.

32 Wilkinson, "The Prosperity Gospel."

33 Marion Maddox, "Prosper, Consume and Be Saved," Critical Research on Religion 1, no. 1 (2013): 111 .

34 Paul-Francois Tremlett, "Two Shock Doctrines: From Christo-Disciplinary to Neoliberal Urbanisms in the Philippines," Culture and Religion 13, no. 4 (2012): 405-423. 
legitimacy for members to desire material gains. In keeping with the historical overview above, the origins of the prosperity gospel in the Philippines can be traced back to the transformative messages carried by early Filipino Pentecostals. ${ }^{35}$ In the 1930s, Filipinos returning from the U.S. established pentecostal congregations such as Filipino Assemblies of God of the First Born (1943), Foursquare Church of Gospel (1937), and Assemblies of God (1953). ${ }^{36}$ These churches offered spiritual and social alternatives for believers to reinterpret their everyday life experiences. Hence, early Pentecostalism offered an alternative to hierarchical Catholicism by espousing a theology of transformation that values social mobility and the deepening of personal faith.

Based on this historical overview, El Shaddai and the many prosperityoriented groups in the Philippines are not only an important innovation in Filipino religiosity but a continuation of the narrative of transformation. ${ }^{37}$ As we will explain later, El Shaddai's prosperity gospel is undeniably influenced by Kenneth Hagin and Oral Roberts. ${ }^{38}$ Apart from being a divine will, social mobility is a personal matter based on one's confessions. As a result, the desire for moral and personal transformation reinforces the country's neoliberal policies that transfer the burden for welfare from the state to the individual. ${ }^{39}$

This is the main theme that our project engages. In a way, this is already reflected in the literature that explains its diversity around the world. In the Philippine context, we aim to understand contemporary changes by characterizing the content of the new prosperity gospel. Here the neoliberal dimension is inescapable especially given that these transformations have taken place only in the last decade or so, at the time when the Philippine economy has been making remarkable strides in the region.

35 Wonsuk Ma, "Doing Theology in the Philippines: A Case of Pentecostal Christianity," Asian Journal of Pentecostal Studies 8, no. 2 (2005): 126.

36 Ma, "Doing Theology in the Philippines," 217.

37 Jayeel Cornelio, "Institutional Religion and Modernity-in-Transition: Christianity's Innovations in the Philippines and Latin America," Philippine Studies: Historical and Ethnographic Viewpoints 56, no. 3 (2008): 345-358.

38 Wiegele, Investing in Miracles: El Shaddai and the Transformation of Popular Catholicism in the Philippines, $20-21$.

39 Jean Comaroff, "The Politics of Conviction: Faith on the Neo-Liberal Frontier," in Contemporary Religiosities: Emergent Socialities and the Post-Nation-State, ed. Bruce Kapferer, Kari Telle, and Annelin Eriksen (New York and Oxford: Berghahn, 2010), 17-38. 
To make our case, we conducted textual analysis of influential books written by two Filipino preachers known for their prosperity-oriented messages. Bo Sanchez and Chinkee Tan are Catholic and evangelical preachers, respectively. We chose them for being arguably the most sought-after speakers and authors in the religious circuit in the Philippines. Their books are typically among the bestsellers, which is not surprising given their unmistakable presence in the media. On Facebook alone, Chinkee Tan has 2.3 million followers while Bo Sanchez has 2.5 million. They also have their own programs on television, most of which are uploaded on YouTube. Clearly, they are not just congregational preachers. On various platforms, they motivate their listeners to be spiritual and financially independent.

Bo Sanchez, a lay worker, leads the Light of Jesus Family, a Catholic charismatic renewal movement with outreach around the Philippines and the world. It is known for its weekly gathering called "The Feast," at which members pray, worship, and listen to messages on Christian living. Its growth was made possible by other "feast builders" who are also engaged in writing spiritual materials. The ministries under Sanchez's leadership are diverse, including Shepherd's Voice Radio and TV and several foundations. Bo Sanchez has written many books; we have chosen six that directly relate to financial and spiritual success: 8 Secrets of the Truly Rich: How You Can Create Material Wealth and Gain Spiritual Abundance at the Same Time, ${ }^{40} 8$ Habits of the Happy Millionaire: Create Your Wealth God's Way, ${ }^{41}$ How to Prosper: Learn a Simple 5-point System to Change Your Financial Life Forever!, ${ }^{42}$ How to be a Blessing Magnet: 8 Simple Steps to Attract the Miracles You Need Every Day, ${ }^{43}$ The Abundance Formula: The Four Simple Steps that Make Good People Rich, ${ }^{44}$ and How Good People Like You Can Become Rich: Follow the 4 Simple Laws of Wealth. ${ }^{45}$

40 Bo Sanchez, 8 Secrets of the Truly Rich: How You Can Create Material Wealth and Gain Spiritual Abundance at the Same Time (Quezon City, Philippines: Shepherd's Voice Publications, Inc., 2008).

41 Bo Sanchez, 8 Habits of the Happy Millionaire: Create Your Wealth God's Way (Quezon City, Philippines: Shepherd's Voice Publications, Inc., 2011).

42 Bo Sanchez, How to Prosper: Learn a Simple 5-Point System to Change Your Financial Life Forever! (Quezon City, Philippines: Shepherd's Voice Publications, Inc., 2011).

43 Bo Sanchez, How to Be a Blessing Magnet: 8 Simple Steps to Attract the Miracles You Need Every Day (Quezon City, Philippines: Shepherd's Voice Publications, Inc., 2012).

44 Bo Sanchez, The Abundance Formula: The Four Simple Steps That Make Good People Rich (Quezon City, Philippines: Shepherd's Voice Publications, Inc., 2013).

45 Bo Sanchez, How Good People Like You Can Become Rich: Follow the 4 Simple Laws of Wealth (Quezon City, Philippines: Shepherd's Voice Publications, Inc., 2016). 
The other author whose writings are worth analyzing is Chinkee Tan, who began a career as a pastor for Victory. Victory is among the biggest megachurches in the country, with members who are generally young and university educated. Its churches around the country are typically found in city centers, malls, and university campuses. The front page of his website welcomes the visitor as follows: "Helping you become wealthy and debt-free!" In the background are moving images of his various speaking engagements, which allude to his success as a media personality. But his website downplays his evangelical identity, a strategic move for Tan to engage other sectors. Indeed, his website also features the biggest Philippine companies at which he has spoken, including Jollibee, Philippine Airlines, and Shangri-la Hotels and Resorts. And yet the religious element is clear in his writings. He is the author of many books on spirituality and financial freedom, seven of which have been analyzed for this study: For Richer and For Poorer: Why the Rich Get Richer and the Poor Get Poorer, ${ }^{46}$ Rich God Poor God: Why God Wants You to Prosper, ${ }^{47}$ How I Made My First Million through Direct Selling and How You Can Too!, 48 Till Debt Do Us Part: Practical Steps to Financial Freedom, ${ }^{49}$ Raising Up Moneywise Kids: 10 Enriching Money Lessons to Teach Your Kids, ${ }^{50}$ Always Chink +: How to Inspire Yourself to Inspire Others, ${ }^{51}$ Secrets of the Rich and the Successful, ${ }^{52}$ and Happy Wife, Happy Life..$^{53}$

That Bo Sanchez and Chinkee Tan are well-known figures with massive followings makes their writings far more influential than the institutional statements of, say, the Catholic Bishops' Conference of the Philippines (С ВСР). ${ }^{54}$ In

46 Chinkee Tan, For Richer For Poorer (Philippines: Church Strengthening Ministry, INC., 2009).

47 Chinkee Tan, Rich God Poor God: Why God Wants You to Prosper (Philippines: Church Strengthening Ministry, INC., 2010).

48 Chinkee Tan, How I Made My First Million Through Direct Selling and How You Can Too! (Philippines: Church Strengthening Ministry, INC., 2011).

49 Chinkee Tan, Till Debt Do Us Part:Practical Steps to Financial Freedom (Philippines: Church Strengthening Ministry, INC., 2012).

$50 \quad$ Chinkee Tan and Kayla Tan, Raising Up Moneywise Kids: 10 Enriching Money Lessons to Teach Your Kids (Philippines: Church Strengthening Ministry, INC., 2013).

51 Chinkee Tan, Always Chink+: How to Inspire Yourself to Inspire Others (Philippines: Church Strengthening Ministry, INC., 2013).

52 Chinkee Tan, Secrets of the Rich and Successful (Philippines: Church Strengthening Ministry, INC., 2014).

53 Chinkee Tan and Nove Ann Tan, Happy Wife, Happy Life (Philippines: Church Strengthening Ministry, INC., 2014).

54 Jayeel Cornelio and Gideon Lasco, "Morality Politics: Drug Use and the Catholic Church in the Philippines," Open Theology 6 (2020). 
a tangible manner, both Sanchez and Tan are shaping the very character of the prosperity gospel in the Philippines. Their books explain their ideas cogently, which allowed us to characterize their prosperity-oriented messages systematically and assess how unique they are relative to other forms of the prosperity gospel. ${ }^{55}$ For example, Tan and Sanchez, compared to other American prosperity preachers, do not appeal for church offerings or personal donations that become the source of wealth of these spiritual leaders. ${ }^{56}$ Rather, their works and writings focus on testimonies, techniques, and practical tips on how to be wealthy without compromising spiritual growth. They also deviate from church-based preachers in that their writings are widely read by the public. Nevertheless, asserting their uniqueness is not to deny the clear similarities to previous prosperity preachers as they continue to uphold the power of a positive mindset and the transformative potential of their followers.

Our work builds on Mundey's textual analysis of Joel Osteen's Your Best Life Now. ${ }^{57}$ His approach is instructive in determining the theological assumptions that underpin the preacher's prosperity gospel. However, we do not attempt a theological evaluation of Tan's and Sanchez's books. At the same time, we cannot account for the immediate effects of their writings apart from recognizing their popularity as writers and as social media personalities. Rather, we focus on the bases and implications of their writings from the standpoint of the sociology of religion. We now turn to our findings.

The new prosperity gospel in the Philippines has three main characteristics: believing right, thinking right, and doing right. The first one is about having the "right" beliefs about the morality of wealth. The second is about internalizing positive thoughts about becoming weal thy. The last is about following practical steps in acquiring wealth. Taken together, all these three provide the religious justifications for the aspiration to become wealthy and the financial management practices that believers should adopt. The new prosperity gospel, in other

\footnotetext{
55 Yong, "A Typology"

56 Kate Bowler, "Daily Grind:The Spiritual Workday of the American Prosperity Gospel," Journal of Cultural Economy 8, no. 5 (February 16, 2015): 630-636; Debra Mumford, "Rich and Poor in the Kin-Dom of God," Missiology: An International Review 48, no. 1 (2020): 57-63; Mary Wrenn, "Consecrating Capitalism: The United States Prosperity Gospel and Neoliberalism," Journal of Economic Issues 53, no. 2 (2019): 425-432.

Mundey, "The Prosperity Gospel."
} 
words, is not only about believing, confessing, and giving,;8 it is a work ethic that marries biblical principles with financial management. Inspired by critical scholarship on inspirational figures who provide ethical frameworks to make capitalism acceptable, we call this the prosperity ethic. ${ }^{59}$ In what follows, the aim of Bo Sanchez and Chinkee Tan is clear. They want people to have financial freedom while achieving spiritual well-being. Despite their denominational differences, their messages on prosperity and spirituality converge.

\subsection{Believing Right}

A proper mindset is necessary to experience God's blessings. The theological premise is not new: God is a rich God who loves people who, because of their faithful giving, shall receive divine favor. ${ }^{60}$ Verses such as Deuteronomy 8:18 are used to demonstrate that wealth is God's blessing. But worth noting are Tan's and Sanchez's assertions about having a specific mindset when it comes to wealth acquisition. In his account, Tan writes about the link between having a proper mindset and pursuing the proper action to achieve results. For him, "in order to be rich, we must start with a healthy, right mindset with regard to money." ${ }^{11}$ To have a right mindset is to use the "Bible as a reference for the wealth of wisdom it holds about money and success." ${ }^{2}$ The same is true with Sanchez, who, in explaining financial blessings, suggests that to receive blessings begins with "having a mindset to create money."63

What then is the purpose of wealth? For both, wealth is part of God's blessings and must never be self-serving; it must be used to help or "bless" other people. Citing 1 Timothy $5: 8$, both underscore wealth as a means to "serve and enrich others," "to bless the poor," and "to prosper others." ${ }^{4}$ To be mindful of such purpose is to avoid materialism. Examples of initiatives that can satisfy the purpose of wealth include giving funds to church ministries and supporting charity institutions. Quite telling is the fact that Sanchez has a widely promoted Anawim, a foundation that houses abandoned children and elderly. Sharing material blessings for the good of other people is more meaningful since believers "use them for love." ${ }^{5}$ For Tan, money is meant to be enjoyed, shared, and

\footnotetext{
58 Bowler, Blessed.

59 Nicole Aschoff, The New Prophets of Capital (Brooklyn: Verso, 2015).

6o Deji Ayegboyin, "A Rethinking of Prosperity Teaching in the New Pentecostal Churches in Nigeria," Black Theology: An International Journal 4, no. 1 (2006): 74.

61 Tan, Till Debt Do Us Part, 2.

62 Tan, Till Debt Do Us Part, 12.

63 Sanchez, 8 Habits, 94.

64 Tan, Secrets of the Rich, 8-9; Sanchez, 8 Secrets, 51; Sanchez, How to Prosper, 53.

65 Sanchez, How Good People, 17.
} 
used to serve other people by meeting their needs. ${ }^{66}$ He claims that "money if used properly can bless the world." ${ }^{67}$ Both authors caution their readers about their motives since money itself is not inherently evil. ${ }^{68}$ What is clear here is that both give a moral dimension to the acquisition of wealth.

This is not to discount tithes and offerings. For both authors, money given to God is "investments with the greatest possible returns that no other investments can match." ${ }^{69}$ Although neither claims that giving money to God through the church extracts physical returns from God, both still emphasize the analogy of sowing in which "your harvest will be determined by your giving."70 Sanchez proclaims the Law of Reciprocity, which characterizes giving and receiving as an irrevocable principle. Believers can expect the blessings to be more than what they have given. ${ }^{71}$ The continuity with older forms of the prosperity gospel is clear.

\subsection{Thinking Right}

The prosperity ethic also encourages believers to internalize a specific mindset about getting rich. To be sure, both Tan and Sanchez believe that God desires people to prosper. ${ }^{72}$ They take Jeremiah 29:11 as a biblical basis. They boldly describe God as a "Business Partner" who gives people the ability to produce wealth. ${ }^{73}$ But they also believe that God would not bless people without preconditions. Having the right attitudes is imperative. Sanchez, for example, rejects what he characterizes as the bahala na (come what may) attitude of many Filipinos. He persuades his readers to be open to acquiring new skills, since "God designed us to work and trust—not just to trust." ${ }^{74}$ In his worldview, having a positive attitude is what attracts favorable opportunities to be successful. Sanchez thus claims that "when you send out a wish, you move the universe to action." 75 Tan echoes this point by calling on his readers to renew

66 Tan, Always Chink+, 39 .

67 Sanchez, 8 Secrets, 195; Sanchez, 8 Habits, 19-20.

68 Tan, Till Debt Do Us Part, 5; Sanchez, How to Prosper, 16.

69 Sanchez, The Abundance Formula, 71; Tan, Rich God Poor God, 94; Sanchez, How Good People, 58 .

$70 \quad$ Sanchez, 8 Secrets, 191.

71 Sanchez, How Good People, 121.

72 Tan, Rich God Poor God, 41; Sanchez, How Good People, 16; Sanchez, How to Prosper, 15, 19.

73 Tan, Secrets of the Rich, 122; Tan and Tan, Raising Up, 134; Tan and Tan, Happy Wife, 104; Sanchez, The Abundance Formula, 54.

74 Sanchez, 8 Secrets, 83-84.

75 Sanchez, How to Be a Blessing Magnet, 54. 
their "thought-life" by adopting a "money mindset."76 Interestingly, Sanchez is more assertive than Tan in arguing that "a wealth mindset is more important than financial literacy" since "money problems are mind problems." 77 He also believes in "the power of beliefs to define reality."78

So, how does belief affect prosperity? According to Sanchez, "the seed of prosperity will grow to the size of your belief." ${ }^{\prime \prime 9}$ To illustrate this, Sanchez dramatically tells the story of Marion Luna Brem. Brem was diagnosed with terminal cancer and divorced by her husband. She incurred huge hospital debt as a result. Desperate, Brem decided to find a job. But she was rejected more than sixteen times. In spite of the failures, Brem carried on with a changed mindset, believing that this should not be the end of her story. After being given two to five years to live, Brem managed to live longer and become successful by building a business empire with millions in annual revenues. With this inspiring story, Sanchez persuades his readers that nothing is impossible for a person with strong determination.

In a way, the positive attitude that both Sanchez and Tan encourage among their readers validates their claim about the morality of wealth. At a closer look, wealth is not morally neutral. Because it is God's blessing, there is nothing morally questionable when people seek it. And given that God also desires to enrich his children to bless other people, having a poverty mindset prevents people from pursuing noble actions. While poverty in itself is not inherently evil, it does limit one's capacity to do greater good, which makes one feel inadequate.

In other words, in the prosperity ethic, it is not sin that is the hindrance to blessings, but one's attitudes. That people are not open to learning and that they are undisciplined are part of this poverty mindset. In fact, both authors consider blaming the government as an act of evading personal responsibility over one's circumstances. Whereas Tan discourages his readers to stop complaining because it is not what rich people do, Sanchez states it more assertively: "Don't blame the government for your poverty. When you blame them, you constantly wait for your salvation from the government. But friend, the government won't save you. Don't wait for prosperity from any politician or government."80

"Thinking right" is an innovation in itself to the older forms of the prosperity gospel that asks believers to "strengthen their faith by memorizing and confess-

\footnotetext{
76 Tan, For Richer For Poorer, 35-39.

77 Sanchez, 8 Habits, 21; Sanchez, How Good People, 19.

78 Sanchez, 8 Secrets of the Truly Rich, 182.

79 Sanchez, How to Prosper, 23.

8 o Sanchez, 8 Secrets, 34 .
} 
ing scriptures." ${ }^{11}$ The battleground, in other words, is not with the confession per se but with what goes on in a person's mind. While the prosperity ethic is, on the surface, an aspiration to be wealthy because it is God's will, it is at its core a longing for redemption not from sin but from the poverty of the mind.

\subsection{Doing It Right}

Finally, the prosperity ethic demands the acquisition of financial skills to enact one's faith. What is unique about Tan's and Sanchez's writings is the untroubled integration of biblical principles with practical skills. In our view, this feature is yet again a distinction from older forms of the prosperity gospel. Both authors embrace the acquisition of financial skills or what we might call rules-based practices. Doing it right, in other words, is as essential as the other elements of the prosperity ethic. We need to spell this out.

To identify which skills matter, their readers need to know the differences between the rich and the poor in terms of their financial beliefs and habits. In the latter chapters of Tan's For Richer and For Poorer, he distinguishes the poor and the rich according to their supposed "lifestyles" and "habits." In his observation, poor people, unlike the rich, value entertainment more than education. When they are invited to a financial seminar, the poor always complain about the expensive seminar fees. Rich people, on the other hand, always find a way to attend these events even for a cost. For Tan, the cost of learning valued by the rich is still less than the cost of ignorance shown by the poor. ${ }^{82}$

Similarly, for Sanchez, the decision to be rich "lies in acquiring a set of specific habits." 83 For Tan, "even if we want to be rich but if we fail to plan to take time in doing the necessary steps to become rich and move towards that direction, we will never be rich" [emphasis ours]. ${ }^{84}$ Attending seminars about financial management and reading about financial literacy are investments that Christians should adopt. Managing expenditures, monitoring cash flows, learning budgeting techniques, entertaining other sources of income, and maintaining a balanced lifestyle are specific prescriptions. To this list could be added other skills such as managing debt, direct selling, and even investing in the stock market, practices that are unheard of in older forms of the prosperity gospel. In fact, Sanchez believes that the "first profit in business is financial wisdom." Apart from reading books, he suggests that believers must seek coun-

\footnotetext{
$81 \quad$ Lee, "Prosperity Theology," 228.

82 Tan, For Richer For Poorer, 190.

83 Sanchez, 8 Habits, 12.

84 Tan, Secrets of the Rich, 6.
} 
sel from financial mentors. ${ }^{85}$ No wonder he offers himself as a financial coach whenever he promotes his personal website on which he gives financial advice on stock investments, for example. Sanchez suggests investing 20 to 30 percent of his readers' money into retail treasury bonds, mutual funds, and the stock market. ${ }^{86}$ On his social media accounts, Sanchez's interviews with other financial mentors are remarkably viral. As we have indicated above, personal testimonies are important in validating their advice and further widening the audience.

For these authors, employment, paper investments, businesses, and activities that generate profit are God-sent "money machines." ${ }^{17}$ Sanchez, in particular, believes that profit is encouraged in the Scriptures. He cites the Parable of Talents (Matt 25:25-26). Biblical scholarship explains talents in terms of spiritual insight about the state of the world and what could be done to make it better. ${ }^{88}$ Thus the parable validates neither capitalism nor profit-making. But in his book, the Catholic lay preacher instructs his readers to "monetize" their God-given gift to overcome financial difficulties. ${ }^{89}$ It means earning money from their talent. Citing from his personal experience, Sanchez writes that he began charging $\mathrm{PhP100,000} \mathrm{(roughly} \mathrm{US} \$ 2,000$ ) for his speaking engagements. Sanchez also recommends to "stick to [your] game," which means focusing on one's skills and specializing in them.

\subsection{The Rise of the Prosperity Ethic}

We end this section by highlighting exactly how the prosperity ethic differs from previous incarnations of the prosperity gospel in the Philippines. Brother Mike Velarde of El Shaddai is emblematic of the "old" prosperity gospel. ${ }^{90}$ Much has been written about him and his ministry, which in itself is indicative of El Shaddai's influence in the Philippines. Claiming to have 9 million members in the country and 2 million more among Filipinos abroad, El Shaddai is arguably the "largest lay Catholic organization in the world."91 Anthropol-

\footnotetext{
85 Sanchez, 8 Secrets, 148.

86 Bo Sanchez, "Truly Rich Club," 2020, https://trulyrichclub.com/.

87 Sanchez, 8 Habits, 93 .

88 Jeff Astley, "The Parable of the Talents," Rural Theology 14, no. 1 (2016): 66-68.

89 Sanchez, The Abundance Formula, 45.

9o Christl Kessler and Jürgen Rüland, "Responses to Rapid Social Change: Populist Religion in the Philippines," Pacific Affairs 79, no. 1 (2006): 73-96; Wiegele, Investing in Miracles.

91 Esmeralda Sanchez and Thomas Landy, "El Shaddai and the Charismatic Transformation of Philippine Catholicism," 20o9, https://www.catholicsandcultures.org/philippines -el-shaddai-serves-largest-population-charismatic-followers\#footnote1_13b1opm.
} 
ogist Katherine Wiegele, who has done extensive work on El Shaddai, claims that it is the largest Catholic charismatic group in the country and that the prosperity gospel is the main feature of its religious life..$^{92}$ But we focus on El Shaddai as the emblem of the "old" prosperity gospel not only because of its massive membership base. El Shaddai has also widened its influence in Filipino society by expanding its presence in the media, formalizing training of its preachers (who are present in local communities around the country), setting up its College of Divine Wisdom (which offers higher education infused with a strong El Shaddai spirituality), and engaging in national politics through its own party in Congress. These developments are not accidental. In 1996, Asiaweek reported that what Brother Mike "most desires ... is to turn around the country's values." ${ }^{93}$ Arguably, El Shaddai has defined the character of the prosperity gospel for many other charismatic groups and congregations in the country.

Like prosperity-oriented preachers elsewhere, the charismatic Brother Mike, as his followers refer to the founder, believes that God is loving and generous toward his children. Since God will care for his children who are dedicated to serving him, there is nothing to worry about, whether it is education, livelihood, or health. ${ }^{94}$ Faith is the tool to improve one's life chances and economic standing. But Brother Mike offers neither practical steps nor financial skills to achieve upward mobility. Instead, the centerpiece of his message is the "seedfaith principle" which teaches that members can expect financial favors from God through voluntary monetary donations..$^{95}$ These donations, as acts of faith, are different from tithing. The money is used for El Shaddai's radio station, private foundations, and partner companies. One's seed-faith donations are to be placed in envelopes where prayer requests may also be inserted. ${ }^{96}$ El Shaddai's prosperity gospel has been a reassuring message for the poor who do not have anything more than their faith that God will bless them because of their tithes and love offerings.

92 Katharine Wiegele, "The Prosperity Gospel among Filipino Catholic Charismatics," in Pentecostalism and Prosperity: The Socioeconomics of the Global Charismatic Movement, ed. Katherine Attanasi and Amos Yong (New York: Palgrave Macmillan, 2012), 171-188. Jose Manuel Tesoro, "Rising Prophet," Asiaweek, November 30, 200o, http://edition.cnn .com/ASIANOW/asiaweek/96/og2o/feat11.html.

94 Christl Kessler and Jurgen Rüland, Give Jesus a Hand! Charismatic Christians: Populist Religion and Politics in the Philippines (Quezon City, Philippines: Ateneo de Manila University Press, 2008), 129.

95 Wiegele, Investing in Miracles, 20.

96 Wiegele, Investing in Miracles, 27. 
In fact, in another writing, Wiegele asserts that this is the very genius of El Shaddai's prosperity gospel. ${ }^{97}$ While mainstream religious discourses of poverty revolve around class struggle and the Catholic view of suffering, Brother Mike has reframed his members' experiences by claiming that they are rich and blessed. As a result, the success of El Shaddai has stemmed the conversion to other religious groups that were emerging especially in the $1980 \mathrm{os}$ and 199os. This renewal of Catholicism among the urban poor has been the major contribution of Brother Mike to religious life in the Philippines. He has effectively borrowed prosperity principles of "seed faith" from Oral Roberts and "faith confession" from Kenneth Hagin, stalwarts of American charismatic Christianity. ${ }^{98}$

By contrast, the new prosperity ethic professed by Chinkee Tan and Bo Sanchez reveals fundamental differences. First, they are both heavily invested in their published books in conveying their message about spirituality and financial success. Second, while both are active members of their respective congregations, neither of them has assumed a central position in the way that Mike Velarde has. They are "testimonies" more than they are "preachers." As we have noted above, stories by both themselves and their followers abound in their writings. Third, they target a very particular set of followers-middleclass and English-reading Filipinos-since they do not rely only on biblical verses for achieving prosperity but also on practical measures to save, invest, and set up businesses. Fourth, unlike Brother Mike, who values congregational attendance and collective assembly, Tan and Sanchez have individualized their spiritual advice about finances by commercializing their books and maintaining online sites from which followers can learn about their success stories. The ethic of the individual is what matters, after all. As we have argued above, the sacralization of the entrepreneurial spirit is at the heart of the new prosperity gospel.

How do we account for the shift? In this final section we wish to offer sociological insights that could account for the rise of the prosperity ethic. Our

97 Katharine Wiegele, "Reframing Suffering and Success through the El Shaddai Movement of the Philippines," Asia-Pacific Social Science Review 5, no. 2 (2005): 68-88.

98 Simon Chan, "Catholic-Pentecostal Relations in Asia: Conflict and Cooperation," in Pentecostalism, Catholicism, and the Spirit in the World, ed. Stan Chu Ilo (Eugene, OR: Cascade, 2019), 137-152. 
observations are limited to the Philippine context, but they could also be considered elsewhere. ${ }^{99}$ The answer, we argue, lies in the economic context. It is very telling that the prosperity-oriented writings of Tan and Sanchez emerged in the mid-20oos. Around this time, the economic liberalization that was introduced in the 199os was beginning to have an impact on international trade, foreign investments, and local manufacturing. ${ }^{100}$ Earlier, these conditions were not present, as a result of the corruption and inefficiency under the dictatorship of Ferdinand Marcos, from which the Philippine economy took a while to recover. ${ }^{101}$ In the 20oos, more government reforms and an improved revenue collection were particularly attractive to investors. Businesses expanded on the back of educated youths. In fact, for the first time in history, that the population was young was no longer considered a liability by economists. Business process outsourcing relied, for example, on an English-speaking and highly educated labor force. By 2012, the Philippines became the forty-fourth largest economy in the world, which, according to HSBC Global Research, could rise even further to sixteenth place by 2050.102 Accompanying this growth has been the rise, too, of the middle class. Economic reports indicate that the middle class expanded from 28.5 percent of the population in 1991 to 40.5 percent in $2015 .{ }^{103}$

While it may not be comparable to that of the country's neighbors, the expansion of the middle class has deepened the formation of the neoliberal habitus in the Philippines. Scholars have documented this formation in different ways. In the 199os, Tadiar for example, noted the construction of spectacular flyovers as spatial transformations catering to Manila's car-owning sector. ${ }^{104}$ For Connell, malls and gated communities, which mushroomed in the same decade, are towering monuments to privatization, consumerism, and individualism. ${ }^{105}$ Urbanism, in other words, met the changing lifestyles of the emerging

\footnotetext{
99 Cornelio and Medina, "Prosperity Ethic."

100 Daniel Joseph Ringuet and Elsa Estrada, "Understanding the Philippines' Economy and Politics since the Return of Democracy in 1986," Contemporary Southeast Asia 25, no. 2 (2003): 233-25o.

101 Ringuet and Estrada “Understanding the Philippines' Economy and Politics."

102 Rappler, "Philippines, 16th Largest Economy in 2050," 2012, https://www.rappler.com/ business/832-philippines,-16th-largest-economy-in-2050.

103 Jose Ramon Albert, Angelo Gabrielle Santos, and Jana Flor Vizmanos, "Profile and Determinants of the Middle-Income Class in the Philippines," PIDS Discussion Paper Series, no. $20(2018)$.

104 Neferti X.M. Tadiar, “Manila's New Metropolitan Form," in Discrepant Histories: Translocal Essays on Filipino Culture, ed. Vicente Rafael (Pasig City: Anvil, 1995), 93-109, https://doi .org/10.2307/20686155.

105 John Connell, "Beyond Manila: Walls, Malls, and Private Spaces," Environment and Planning A: Economy and Space 31, no. 3 (1999): 417-439.
} 
affluent sector. Today middle-class Filipinos are employed in wholesale and retail trade, transportation and communication, and government service. Finishing a college degree is greater among them than it is among the low-income segment. This also explains the heavier investments middle-class parents place on the education of their children, who are usually enrolled in private schools. Ownership of cars and private property is predictably higher among middleclass families as well. ${ }^{106}$ This economic environment has engendered the aspiration for stability among Filipino families. An extensive report by the New York Times sensed the optimism among the rising middle class. Writing about a female call center agent in a business district in Manila, Whaley notes the following: "Had she been born a generation earlier, she would most likely have worked as a low-income farmer or gone overseas to find work. 'My parents didn't have any opportunity like this,' she said."107

The trajectory of the prosperity gospel in the Philippines coincides with the country's recent economic history. For Tremlett, El Shaddai's prosperity gospel "refracted, authorised and legitimated" the neoliberal transformations that took shape in the 199os. ${ }^{108}$ In effect, El Shaddai, through its mass gatherings and media broadcasts, sanctified the desire for moral renewal and upward mobility especially among the urban poor. At the turn of the century, Tan and Sanchez have taken the prosperity gospel to the next level by targeting the aspirational middle class with a religious message that banks not only on faith but also on financial management skills. Using the words of Tremlett, the new prosperity ethic, catering specifically to the aspirational middle class-refracts, authorizes, and legitimates the neoliberal habitus that has accompanied the rise of educated youth, the growth of a highly skilled labor force, and the liberalization of the Philippine economy. Specifically, it provides the religious language not only for the aspiration but also the very practical fulfillment of the good life, for which the individual has the sole burden of making it happen.

In effect, their work infuses self-help with a strong religious character. Selfhelp literature, promoting individual responsibility, flourishes in a marketized society, ${ }^{109}$ providing a blueprint for individuals to transform their ways of

\footnotetext{
106 Albert, Santos, and Vizmanos, "Profile and Determinants."

107 Floyd Whaley, "A Youthful Populace Helps Make the Philippines an Economic Bright Spot in Asia," 2012, http://www.nytimes.com/2012/o8/28/business/global/philippine-economy -set-to-become-asias-newest-bright-spot.html.

108 Tremlett, "Two Shock Doctrines."

109 Jeffrey Kenney, "Selling Success, Nurturing the Self: Self-Help Literature, Capitalist Values, and the Sacralization of Subjective Life in Egypt," International Journal of Middle East Studies 47 (2015): 663-68o, https://doi.org/10.1017/Soo207438150oog26; Angelia Poon, "Helping the Novel: Neoliberalism, Self-Help, and the Narrating of the Self in Mohsin Hamid's How
} 
thinking and doing to achieve a subjectivity that meets the expectations of the neoliberal economy. ${ }^{110}$ Like Tan's and Sanchez's books, self-help materials thrive based on readers' assumed life-needs, which can be addressed by following practical steps that the authors have proven to be effective for themselves as well. The assumption is that the self "can be contacted, explored, and empowered with the right knowledge and technique."111 Adopting the neoliberal ethos, self-help materials emphasize self-reliance, industriousness, and discipline. ${ }^{112}$ By marrying financial skills with biblical principles, the new prosperity ethic is religious self-help. This neoliberal Christianity believes being positive is a "life resource" that becomes the basis for "citizens to be self-constituting and resourceful."113 Principles of spiritual well-being and the neoliberal market maximize welfare at the level of "the individual."114

This is why the books written by Tan and Sanchez have found favor among the aspirational middle class (and among Catholics and Evangelicals alike). They are educated readers of English who can appreciate the logic and discipline of financial management and to whom personal testimonies of success and renewal are validations of what Tan and Sanchez preach. But this may also allude to the reflexive spirituality of contemporary Christians in the Philippines in which faith must resonate with everyday experiences. ${ }^{115}$ Thus, to a great extent, the denominational differences between Tan and Sanchez no longer matter. That they couch their message in the language of the Bible legitimates it in a religious society like the Philippines. ${ }^{116}$ In the introduction to his book Rich God Poor God, Tan asserts that Christianity is "not about prosperity and money" but then goes on to show that "the Bible has 5oo verses on money and possessions ... This only reveals that God wants us to know that our concerns are His concerns. He talked about money matters because money also matters to Him."117

to Get Filthy Rich in Rising Asia," The Journal of Commonwealth Literature 52, no. 1 (2015): 139-150; Janice Peck, "The Secret of Her Success: Oprah Winfrey and the Seductions of Self-Transformation," Journal of Communication Inquiry 34, no. 1 (2010): 7-14.

110 Kenney, "Selling Success," 664.

111 Kenney, "Selling Success," 664-666.

112 Poon, "Helping the Novel," 141.

113 Bowler, "Daily Grind," 631.

114 Moberg and Martikainen, "Religious Change," 420.

115 Cornelio, "Popular Religion and the Turn to Everyday Authenticity"; Jayeel Cornelio, Being Catholic in the Contemporary Philippines: Young People Reinterpreting Religion (London and New York: Routledge, 2016).

116 Cornelio, "The Philippines," 2020.

117 Tan, Rich God Poor God, 13. 
The prosperity ethic is emblematic of a neoliberal Christianity that places Tan and Sanchez among the ranks of the new prophets of capital, who, while troubled by the harshness of poverty, nevertheless place the burden back on the individual to navigate their lives and economic fortunes. ${ }^{118}$ The prosperity ethic, therefore, is a novel technology that governs the contemporary individual, who is both religious and entrepreneurial. Whereas psychotherapy, personnel management, and other sciences have come together over the twentieth century to manage the self as a choosing individual, religion today joins the scene through the prosperity ethic. Its view of the individual remains the same: "Selves dissatisfied with who they are can engage in therapeutic projects to refurbish and reshape themselves in the directions they desire."119 While promising hope in God who blesses, the prosperity ethic also calls upon individuals to seal their very aspirations by changing their ways. The message works for a society that is not only religious but also driven by the ambition to lift itself out of poverty.

\section{5}

\section{Conclusion: The Limits of Neoliberal Christianity}

Based on our analysis of Tan's and Sanchez's books, believing right, thinking right, and doing it right are the three facets of the prosperity ethic. As influential preachers and writers, they are shaping the very character of the contemporary prosperity gospel. In effect, the prosperity ethic they espouse values upward mobility and draws on the Bible to explain how wealth is to be acquired. Given their influence, their contributions need to be considered seriously in understanding the prosperity gospel not just in the Global South but around the world. ${ }^{120}$ In other words, while attention may be given, for example, to Joel Osteen as the embodiment of faith and consumerism, Bo Sanchez and Chinkee Tan are also worth the scholarly attention. ${ }^{121}$ In our view, to isolate our analysis as a unique development in the Global South runs the risk of exoticizing this form of the prosperity gospel when, it fact, it mirrors the very marketization of society discernible in other contexts. ${ }^{122}$

\footnotetext{
118 Aschoff, The New Prophets of Capital.

119 Nikolas Rose, Governing the Soul, 2nd ed. (London: Free Association Books, 1989), 232.

120 Ron MacTavish, "Pentecostal Profits: The Prosperity Gospel in the Global South," Religious Studies (Master's thesis, University of Lethbridge, 2014).

121 Mundey, "The Prosperity Gospel."

122 Moberg and Martikainen, "Religious Change."
} 
We wish to end on a critical note. The neoliberal habitus that accompanied the expansion of the middle class is what has made the rise of the prosperity ethic possible in the past decade or so. This middle class, even if limited or precarious, is aspirational. An irony exists here though. The individualistic desire for upward mobility and economic stability is indifferent to the failure of the public sector to address the basic needs of Filipinos. ${ }^{123}$ But this indifference is also what deepens the desire. No wonder both Sanchez and Tan ask their readers to take responsibility for their own progress in life; the government cannot be blamed for their own circumstances. In effect, apart from "blessing neoliberalism," the prosperity ethic is also depoliticizing Christianity. ${ }^{124}$

A related concern lies in individualizing poverty. In our view, the theological baggage of the prosperity ethic, for valuing hard work, renders poverty as the problem of the lazy. Indeed, Tan himself claims that "poor people put more value on entertainment than educating themselves." ${ }^{125}$ We cannot neglect this point because in spite of its stellar performance, the country's economic growth has historically lagged compared to its neighbors. The reality is that achieving financial security is a daily struggle for the majority, including the precarious middle class, the targeted consumers of the prosperity ethic. To lay the blame on the individual thus takes for granted the social conditions that arrest one's capacity to improve personal fortunes. And yet this inadequacy at the same time calls into question the place of human dignity in a theology of work whose central desire is to be prosperous. ${ }^{126}$

\section{Acknowledgments}

This publication is based on a project funded by the International Collaboration Grant of the Global Religion Research Initiative at the University of Notre Dame. The grant recipients are James Densley, Andrew Johnson, and Jayeel Cornelio.

\footnotetext{
123 Connell, "Beyond Manila."

124 Zeynep Kurtulus Korkman, "Blessing Neoliberalism: Economy, Family, and the Occult in Millennial Turkey," Journal of the Ottoman and Turkish Studies Association 2, no. 2 (November 2015): 335 .

125 Tan, For Richer For Poorer, 138.

126 John Hughes, The End of Work: Theological Critiques of Capitalism (Malden, MA and Oxford: Blackwell, 2007).
} 